\title{
Modeling International Trade Flows between CEEC and OECD Countries
}

\author{
CHRISTOPHE RAULT \\ ROBERT SOVA \\ ANA MARIA SOVA
}

CESIFO WORKING PAPER NO. 2282

CATEGORY 7: TRAde POLICY

APRIL 2008

\footnotetext{
An electronic version of the paper may be downloaded

- from the SSRN website:

www.SSRN.com

- from the RePEc website:

- from the CESifo website:

www.RePEc.org

www.CESifo-group.org/wp
} 


\title{
Modeling International Trade Flows between CEEC and OECD Countries
}

\begin{abstract}
This article deals with econometric developments for the estimation of gravity model, which allow to get convergent parameter estimates even when a correlation exists between the explanatory variables and the specific unobservable characteristics of each individual. We implement panel data econometric techniques to characterize bilateral trade flows between heterogeneous economies. Our econometric results based on a sample of 4 Central and Eastern European countries (CEEC-4) and 19 OECD countries over a 18-year period highlight the importance by taking into account the unobservable heterogeneity to obtain a robust empirical specification and unbiased coefficients.
\end{abstract}

JEL Code: F13, F15, C23.

Keywords: gravity models, unobservable heterogeneity, panel data models, international trade flows.

\author{
Christophe Rault \\ University of Orléans \\ LEO, CNRS, UMR 6221 \\ Rue de Blois-B.P. 6739 \\ 45067 Orléans Cedex 2 \\ France \\ chrault@hotmail.com
}

\author{
Robert Sova \\ Sorbonne University Paris I \\ E.B.R.C. and A.S.E \\ 106-112 bd. de L'Hôpital \\ 75647 Paris Cedex 13 \\ France \\ robertsova@yahoo.com
}

\author{
Ana Maria Sova \\ Sorbonne University Paris I \\ E.B.R.C. and A.S.E \\ 106-112 bd. de L'Hôpital \\ 75647 Paris Cedex 13 \\ France \\ anamariasova@yahoo.fr
}




\section{Contents}

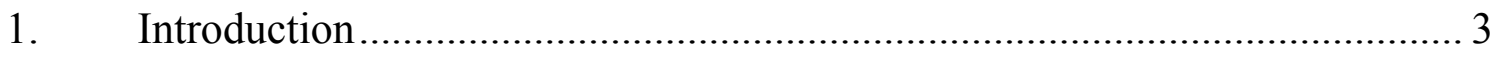

2. Theoretical Foundations of the Gravity Model........................................... 4

3. The Econometric Methodology ................................................................. 6

3.1 Pooled Ordinary Least Square (POLS) ................................................ 7

3.2 Within estimator and random estimator (FEM and REM) ...................... 8

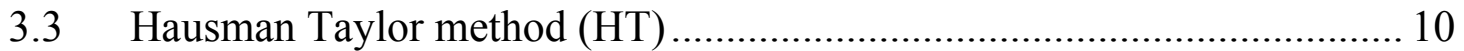

4. The Empirical Investigation............................................................... 11

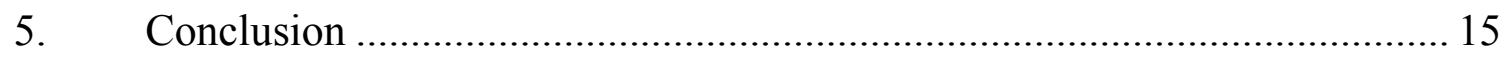

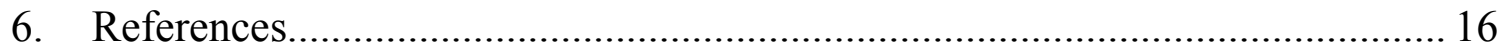




\section{Introduction}

The aim of this article is to examine and characterize trade relationships between a set of developing and developed countries using recent advances in the econometrics of panel data techniques with fixed effects, which permit to take the unobserved heterogeneity of country behaviour over time into account. Our database includes 4 Central and Eastern European countries ${ }^{4}$ (CEEC-4) and 19 OECD countries ${ }^{5}$ (including the European Union, EU-15) ${ }^{6}$. In our mind this set of heterogeneous economies constitutes a relevant and interesting framework worth being analysed.

First of all, we propose an evaluation of the type of trade and of the specialization degree of economies. In particular, we are interested in determining whether CEEC countries continued to specialize in labour intensive industries with their comparative advantage of less expensive labour costs and hence, have developed an inter-industry trade, or on the contrary, have generated an intra-industry trade related to an economic convergence. CEEC countries aim at reducing their economic development gap and to intensify the convergence process between these two groups of economies ${ }^{7}$ and hence, the competition in the area.

The various theories of international trade permit to release those which are the most relevant in the analysis of trade flows between CEEC and $\mathrm{OECD}^{8}$ countries. Our approach is based on the gravity equation, which is suitable to the analysis of intra-industry trade as well adapted as to the analysis of inter-industry trade. More precisely, it allows to characterize the type of trade and hence, the specialization in a certain moment.

\footnotetext{
4 Hungary, Poland, Bulgaria and Romania, which became new member states of the European Union on May 2004 and January 2007.

5 EU-15: Austria, Belgium-Luxemburg, Denmark, England, Finland, France, Germany, Greece, Holland, Ireland, Italy, Portugal, Spain, Sweden; nonEU countries: Australia, Canada, Japan, Switzerland, the United States of America.

6 Moreover, CEEC countries exchange with the EU-15 countries almost $70 \%$ of the total trade.

7 CEEC and OECD countries.

8 Organization for Economic Cooperation and Development.
} 
In international trade, the gravity model is widely used as a basic model for estimating the effect of regional agreements, the effect of the monetary union on trade flows and to simulate the trade potential ${ }^{9}$.

From an econometric point of view, the choice of the econometric methodology is in accordance with the recent developments of panel data methods, which explicitly take unobserved heterogeneity into account. In fact, the standard crosssection estimates tend to ignore the unobservable characteristics of bilateral trade relationships (historical, cultural and linguistic links). The existence of a potential correlation between the unobservable characteristics and a subset of the explanatory variables run the risk of obtaining biased estimates (cf. Baltagi, 2001). A possible method to eliminate this correlation consists in using the within estimator. In transforming the data into deviations from individuals means, the within estimator provides unbiased and consistent estimates. However, all time invariant variables are eliminated by the data transformation. To overcome this problem, Hausman and Taylor (1981) propose an instrumental variable estimator for panel data regression.

The remainder of this article is organized as follows. Section II presents an overview of the theoretical foundations of the gravity model. Section III exposes our panel data methodology. Section IV reports the empirical investigation as well as our econometric results and finally Section V discusses the policy implications and concludes.

\section{Theoretical Foundations of the Gravity Model}

Inspired initially by the law of physics (Newton), the gravity model has become an essential tool in the simulations of international trade flows. The first applications were rather intuitive without substantial theoretical claims. These applications were the object of critics concerning the lack of robust theoretical foundations. Among the first studies which

9 See, for instance Bayoumi and Eichengreen (1997), Frankel (1997), Matyas (1997), Wei and Frankel (1998), Rose (2000), Soloaga and Winters (2001), Ghosh and Yamarick (2004), Baier and Bergstrand (2005), Cheng and Wall (2005), Carrère (2006), Rault and Sova (2007). 
have used the gravity model in economic analysis, can note those by Beckerman (1956), Tinbergen (1962), Poyhonen (1963), Linnemann (1966), and Aitken (1973).

Linnemann explains trade flows between countries $\boldsymbol{i}$ and $\boldsymbol{j}$ and then defines it as a combination of three factors: the offer of the exporter country $\boldsymbol{i}$, the demand of the importer country $\boldsymbol{j}$ and the resistance of trade between countries $\boldsymbol{i}$ and $\boldsymbol{j}$. The potential offer of the exporter is a positive function of the income level of the exporter country which can be interpreted as a proxy of available good varieties. The potential demand of the importer country also depends positively of the income level of the importer country. In other words, the national incomes of two countries $\boldsymbol{i}$ and $\boldsymbol{j}$, transport costs (transaction costs) and regional agreements are the basic determinants of the model.

Gravity models have received theoretical foundations due to the development of new international trade theories with imperfect competition. Helpman and Krugman (1985) propose a formalization of the gravity equation, in which the intra-trade and inter-trade approaches are reconciled.

Bergstrand (1989) model represents an extension of Helpman and Krugman model, taking into account the offer and the demand functions in explaining trade flows. The model also includes a variable of income per capita representing the capital intensity of the exporter country and of the importer country, reflecting a relative factor endowment in terms of GDP per capita. For this author this variable is an indicator of demand sophistication. The required goods may be either luxury or necessity goods. Bergstrand proposes the most complete version of the gravity model using for instance, variables like GDP, GDP per capita, distance and monetary variables.

The gravity model has been widely used in the applied literature to evaluate the impact of regional agreements, the impact of a monetary union, the impact of Foreign Direct investments (FDI) on trade flows and to simulate the trade potential ${ }^{10}$. After this brief

10 Bayoumi and Eichengreen (1997) note that 'the gravity equation has long been the workhorse for empirical studies of the pattern of trade'. 
overview of the theoretical foundation of the gravity model, we are now interested in finding the appropriate empirical specification of this model to better characterize the trade flows between countries with a different economic development level (heterogeneous economies), more particularly between CEEC and OECD countries. In the next section, we present the econometric methodology, which rests upon panel data techniques.

\section{The Econometric Methodology}

Most studies estimating a gravity model were carried out on cross-section data ${ }^{11}$. Recently several papers have argued that standard cross-section methods lead to biased results because they do not control for heterogeneous trading relationships. For instance, the impacts of historical, cultural and linguistic link trade flows are difficult to observe and to quantify, the presence of minorities or past memberships in a common trade area can also lead to biased estimates. Panel data regressions allow to correct for such effects. The use of panel data is preferred in our analysis because it allows to control for specific effects (as fixed or random effects). The source of potential endogeneity bias in gravity model estimations is the unobserved individual heterogeneity.

Matyas (1997) argues that cross-section approach is affected by a problem of misspecification and consider that a correct econometric specification of gravity model is a 'three-way model' with exporter, importer and time effects (random or fixed effects). Concerning panel data, Egger (2000) mentions that the most appropriate methodology is for disentangling time-invariant and country-specific effects.

Egger and Pfaffermayr (2003) indicate that the omission of specific effects per country pair can biased the estimated coefficients. An alternative solution is to use an estimator to control for bilateral specific effects like fixed-effects model (FEM) or random-effects model (REM).

11 See Baldwin (1994), Gros and Gonciarz (1996), Wei and Frankel (1998) and Sapir (2001). 
However, FEMs allow for unobserved or misspecified factors that simultaneously explain trade volume between two countries and lead to unbiased and efficient results ${ }^{12}$.

The choice of the method (FEM or REM) depends on two important things, its economic and econometric relevance. From an economic point of view, there are unobservable time invariant random variables, difficult to be quantified, which may simultaneously influence some explanatory variables and the trade volume. From an econometric point of view, the inclusion of fixed effects is preferable to random effects because the rejection of the null assumption of uncorrelation of the unobservable characteristics with some explanatory variables is less plausible (Baier and Bergstrand, 2005).

We now briefly present the panel data econometric methods 13 used in our article to estimate the possible various specifications of our models: pooled ordinary least squares (POLS), random effect estimator (REM), within estimator (FEM) instrumental variables Hausman-Taylor estimator (HT).

\subsection{Pooled Ordinary Least Square (POLS)}

The class of models that can be estimated using a pooled ordinary least squares estimator can be written as follows

$$
y_{i t}=\beta x_{i t}^{\prime}+\alpha z_{i}^{\prime}+\varepsilon_{i t} \quad \mathrm{i}=1,2, \ldots, \mathrm{N}, \mathrm{t}=1,2, \ldots, \mathrm{T}
$$

, where $\mathrm{y}_{\mathrm{it}}$ is the dependent variable, $\mathrm{x}_{\mathrm{it}}$ are $\mathrm{K}$ regressors not including a constant term. The heterogeneity or individual effect is $\alpha z_{i}^{\prime}$ where $\mathrm{z}_{\mathrm{i}}$ contains a constant term and a set of

12 See for instance, Festoc (1997), Matyas (1997), Rose (2000), Glick and Rose (2002), Egger (2002), Ghosh-Yamarick (2004), Baier and Bergstrand (2005), Cheng and Wall (2005), Carre` re (2006) and Peridy (2006).

13 See Wooldridge $(2002,2005)$ and Hausman-Taylor (1981). 
individual or group specific variables, which may be observed or unobserved, all of which are taken to be constant over time t.

Ordinary Least Squares (OLS) is often used to estimate the gravity model but does not permit to control the individual heterogeneity and hence may yield to biased results due to a correlation between some explanatory variables and some unobservable characteristics. If the Breusch Pagan LM test rejects the null hypothesis in favor of random effects, the OLS method is not adequate.

\subsection{Within estimator and random estimator (FEM and REM)}

In the presence of correlation of the unobserved characteristics with some explanatory variables random effect estimator leads to biased and inconsistent parameter estimates. For eliminating this correlation it is possible to use a traditional method called "within estimator or fixed effects estimator" which consists in transforming the data into deviations from individual means. In this case, even if a correlation between unobserved characteristics and some explanatory variables exists, the within estimator may provide unbiased and consistent results.

The fixed effects model can be written as

$y_{i t}=\sum_{k=1}^{K} \beta_{k} x_{k i t}+\alpha_{i}+u_{i t}, \mathrm{t}=1,2, \ldots, \mathrm{T} ; \quad \mathrm{k}=1,2, . ., \mathrm{K}$ regressors; $\mathrm{i}=1,2, ., \mathrm{N}$ individuals

, where $\alpha_{\mathrm{i}}$ denotes individual effects fixed over time and $\mathrm{u}_{\mathrm{it}}$ is the disturbance terms.

If we subtract from (2) the average over time of (2) we obtain the fixed effects transformation as:

$$
y_{i t}-\bar{y}_{i}=\sum_{k=1}^{K} \beta_{k}\left(x_{k i t}-\bar{x}_{k i}\right)+\left(u_{i t}-\bar{u}_{i}\right)
$$


In the fixed effects transformation, the unobserved effect, $\alpha_{i}$, disappears because it is fixed over time. A pooled OLS estimator based on equation (3), called fixed effects estimator or within estimator, may lead to unbiased and consistent results.

The random model has the same form as in (2),

$$
Y_{i t}=\beta_{0}+\beta_{1} \mathrm{x}_{\mathrm{it1}}+\beta_{2} \mathrm{x}_{\mathrm{it} 2} \ldots \ldots \ldots \ldots \ldots+\beta_{\mathrm{k}} \mathrm{x}_{\mathrm{itk}}+\alpha_{\mathrm{i}}+\mathrm{u}_{\mathrm{it}}
$$

, where an intercept is included so one can make the assumption that the unobserved effect, $\alpha_{i}$, has zero mean (without loss of generality), see Wooldridge (2005).

Equation (4) becomes a random effect model when we assume that the unobserved effect $\alpha_{\mathrm{i}}$ is uncorrelated with each explanatory variable:

$$
\operatorname{Cov}\left(x_{i t k}, \alpha_{\mathrm{i}}\right)=0, \quad t=1,2, \ldots, T ; j=1,2, \ldots, k
$$

The hypothesis mentioned above is actually less plausible and the GLS estimator may lead to biased results.

The Hausman $\left(\mathrm{chi}^{2}\right)$ test consists in testing the null hypothesis of no correlation between unobserved characteristics and some explanatory variables and allows us to make a choice between random estimator and within estimator. The within estimator has however two important limits:

it may not estimate the time invariant variables that are eliminated by the data transformation;

fixed effects estimator ignores variations across individuals. The individual's specificities can be correlated or not with the explanatory variable. In traditional methods these correlated variables are replaced with instrumental variables uncorrelated to unobservable characteristics. 


\subsection{Hausman Taylor method (HT)}

Hausman Taylor (1981) estimator (hereafter HT) overcomes this problem using a method which allows to consider some explanatory variables included in the model as instruments. In this case the major difficulty of instrumental methods which consists in finding external instruments (not from original specification) and uncorrelated with unobservable characteristics is avoided. The considered equation is as follows:

$$
Y_{i t}=\beta_{0}+\beta_{1} X_{i t}^{1}+\beta_{2} X_{i t}^{2}+\mathrm{Y}_{1} Z_{i}^{1}+\mathrm{Y}_{2} Z_{i}^{2}+\alpha_{i}+\eta_{i t}
$$

, with the condition that the explanatory variables are not correlated with $\eta_{i t}$, even if some of them are correlated with $\alpha_{\mathrm{i}}$.

Our explanatory variables are divided into four categories: time varying uncorrelated $\left(\mathrm{X}^{1}{ }_{\mathrm{it}}\right)$, time varying correlated with $\alpha_{\mathrm{i}}\left(\mathrm{X}^{2}{ }_{\text {it }}\right)$, invariant uncorrelated $\left(\mathrm{Z}_{\mathrm{i}}^{1}\right)$ and invariant correlated with $\alpha_{i}\left(Z^{2}{ }_{i}\right)$.

The $\mathrm{X}_{\mathrm{i}}^{2}$ regressors are instrumented by the deviation from individual means (as in the Fixed Effect aproach) and the $\mathrm{Z}^{2}$ regressors are instrumented by the individual average of $\mathrm{X}^{1}{ }_{\text {it }}$ regressors. Hausman Taylor estimator allows us to estimate the effect of time-invariant variables such as distance, common border, common languages etc. Hausman Taylor (HT) estimator doesn't use external instruments.

The variables are divided into two matrices. The $X$ matrix contains $k_{1}$ columns of $X^{1}{ }_{\text {it }}$ and $k_{2}$ columns $X^{2}$ it and the $Z$ matrix contains $g_{1}$ columns of $Z^{1}$ and $g_{2}$ columns of $Z_{i}^{2}$. The variables to be instrumented are $X^{2}{ }_{i t}$ and $Z^{2}$. The set of instruments proposed by HT is the following one: $\left(\mathrm{QX}^{1}{ }_{\mathrm{it}}, \mathrm{QX}^{2}{ }_{\mathrm{it}}, \mathrm{PX}^{1}{ }_{\mathrm{it}}, \mathrm{Z}^{1}{ }_{\mathrm{i}}\right)$, where $\mathrm{k}_{1}>\mathrm{g}_{2}$. The deviations to the average (Q) are those that eliminate the correlation of the variable $\mathrm{X}^{2}$ it, and the $\mathrm{X}^{1}{ }_{\mathrm{it}}$ averages corrects for the $Z^{2}{ }_{i}$ variables (with the condition that the number of $X^{1}{ }_{\text {it }}$ uncorrelated variables is larger or at least equal to the number of $Z^{2}$ i correlated variables, that is to say $k_{1} \geq g_{2}$ ). Because of error autocorrelation the estimated coefficients are not efficient even if they are unbiased. For this reason Hausman Taylor use predefined instruments to get unbiased and efficient results. When the model is overidentified $\left(k_{1}>g_{2}\right)$ these estimators are more efficient than those of the within model. To test for the assumption of no-correlation of the $\mathrm{X}^{1}{ }_{\text {it }}$ and $\mathrm{Z}_{\mathrm{i}}^{1}$ variables one can compare the within estimators with those of HT. 


\section{The Empirical Investigation}

We carry out several panel data estimations in order to compare the results across specifications and to identify the most robust one. We first make a test for individual effects and if this confirms their presence, then for controlling the individual effects we carry out an REM and FEM estimate. To eliminate the unobservable heterogeneity due to bilateral specific effects and to avoid the potential bias of the estimators taking into account for the invariant time variables it is advisable to use Hausman Taylor estimator. Hausman test indicates by the value of $\mathrm{chi}^{2}$ whether the specific effects are correlated or not with the explanatory variables.

The specification retained here to characterize the trade between CEEC and OECD countries can be written as follows:

$$
X_{i j t}=e^{a_{0}} G D P_{i t}^{a_{1}} G D P_{j t}^{a_{2}} D G D P T_{i j t}^{a_{3}} \operatorname{Dist}_{i j}^{a_{4}} \operatorname{Tcrh}_{i j t}^{a_{5}} e^{a_{6} A c c_{i j t}} e^{a_{7} C l_{i j}} e^{a_{8} C b_{i j}} e^{a_{9} D_{t}} e^{\varepsilon_{i j t}}
$$

where :

$>\mathrm{X}_{\mathrm{ijt}}$ denotes the bilateral trade between countries $\boldsymbol{i}$ and $\boldsymbol{j}$ at time $\boldsymbol{t}$ with $\mathrm{i} \neq \mathrm{j}$ (CHELEM - CEPII French data base);

$>\mathrm{a}_{0}$ is the intercept;

$>\mathrm{GDP}_{\mathrm{it}}, \mathrm{GDP}_{\mathrm{jt}}$ represents the Gross Domestic Product of country $\boldsymbol{i}$ and country $\boldsymbol{j}$ (CHELEM CEPII - data base)

$>$ DGDPT $_{\mathrm{ijt}}$ is the difference of GDP per capita between partners and is a proxy of economic distance or of comparative advantage intensity,

$D G D P T_{i j t}=\left|\frac{G D P_{i t}}{P O P_{i}}-\frac{G D P_{j t}}{P O P_{j}}\right|$

where $\mathrm{POP}_{\mathrm{i}(\mathrm{j})}$ is the population (CHELEM CEPII data base);

Dist $_{\mathrm{ij}}$ represents the distance between two countries, (CEPII data base);

$>\mathrm{Tcrh}_{\mathrm{ijt}}$ is the real exchange rate which indicates the competitiveness of price;

$$
T c h r_{i j t}=T c n_{i j t} \times P_{i t} / P_{j t}
$$

where: $\mathrm{Tcn}_{\mathrm{ijt}}$ is the real exchange rate (CHELEM CEPII data base) 


$$
\mathrm{P}_{\mathrm{i}(\mathrm{j})} \text { is consumer price index (WORLD BANK - World Tables) }
$$

Acc $_{\mathrm{ijt}}$ is a dummy variable that equals 1 if country $\boldsymbol{i}$ and country $\boldsymbol{j}$ have signed a regional agreement, and zero otherwise,

$>\mathrm{Cl}_{\mathrm{ij}}$ is a dummy variable that equals 1 if country $\boldsymbol{i}$ and country $\boldsymbol{j}$ are membership to a International Organization (Francophone International Organization), and zero otherwise,

$>\mathrm{Cb}_{\mathrm{ij}}$ is a dummy variable which indicates a common border,

$>\mathrm{D}_{\mathrm{t}}$ is a time-dummy variable,

$>\varepsilon_{\mathrm{ijt}}$ is the error term.

After log linearization equation (6) becomes:

$\mathrm{Ln}\left(\mathrm{X}_{\mathrm{ijt}}\right)=\mathrm{a}_{0}+\mathrm{a}_{1} \ln \left(\mathrm{GDP}_{\mathrm{it}}\right)+\mathrm{a}_{2} \ln \left(\mathrm{GDP}_{\mathrm{jt}}\right)+\mathrm{a}_{3} \ln \left(\mathrm{DGDPT}_{\mathrm{ijt}}\right)+\mathrm{a}_{4} \ln \left(\right.$ Dist $\left._{\mathrm{ij}}\right)+\mathrm{a}_{5} \ln \left(\mathrm{Tchr}_{\mathrm{ijt}}\right)+\mathrm{a}_{6} \mathrm{Acc}_{\mathrm{ijt}}+$ $\mathrm{a}_{7} \mathrm{Cl}_{\mathrm{ij}}+\mathrm{a}_{8} \mathrm{Cb}_{\mathrm{ij}}+\mathrm{a}_{9} \mathrm{D}_{\mathrm{t}}+\varepsilon_{\mathrm{ijt}}$

The expected signs for the estimators associated with the variables are based on traditional arguments. Theoretically, we expect a positive effect on trade flows of variables like the country size, the association agreement, the common language, the common border and a negative impact of geographical distance and of real exchange rate. The more the real exchange rate index drops the more there is a depreciation of the exporter currency with respect to the currency of his partner and hence export competitiveness is improved. Concerning the sign of the difference of GDP per capita, it is positive if the HeckscherOhlin (H-O) assumptions are confirmed. On the contrary, according to the new trade theory, the income per capita variable between countries is expected to have a negative impact. According to the classical theory, an increase in the intensity of comparative advantages should involve an increase in trade flows. Countries very different in factors endowments and in comparative advantages would exchange more between them. Geographical distance has theoretically always a negative impact being a proxy of transport costs. Our estimates are organized in a panel way with four CEEC and 19 OECD countries, including EU -15 countries which are the main partners for CEEC-4. The data used cover a 18 year period (from 1987 to 2004). The results of FEM, REM and HT estimations are reported in Table 1. 
Table 1: The results of FEM, REM, and HT estimations

\begin{tabular}{|c|c|c|c|}
\hline \multirow[t]{3}{*}{ VARIABLES } & $\begin{array}{l}\text { Within + } \\
\text { time effects }\end{array}$ & $\begin{array}{l}\text { Random } \\
\text { effects }\end{array}$ & $\begin{array}{l}\text { Hausman } \\
\text {-Taylor }\end{array}$ \\
\hline & (1) & (2) & (3) \\
\hline & $\mathbf{X}_{\mathbf{i j t}}$ & $\mathbf{X}_{\mathrm{ijt}}$ & $\mathbf{X}_{\mathrm{ijt}}$ \\
\hline \multirow[t]{2}{*}{$\ln \left(G^{\prime} P_{\text {it }}\right)$} & 0.457 & 0.697 & 0.457 \\
\hline & $(3.78)^{* * *}$ & $(8.76)^{* * *}$ & $(3.78) * * *$ \\
\hline \multirow[t]{2}{*}{$\ln \left(G^{\prime} P_{j t}\right)$} & 0.914 & 0.977 & 0.914 \\
\hline & $(4.45)^{* * *}$ & $(16.94)^{* * *}$ & $(4.44)^{* * *}$ \\
\hline \multirow[t]{2}{*}{$\ln \left(\right.$ Dist $\left._{i j}\right)$} & - & -1.204 & -1.621 \\
\hline & - & $(-14.08)$ & $(-2.56) * * *$ \\
\hline \multirow[t]{2}{*}{$\ln \left(\mathrm{DGDPT}_{\mathrm{ijt}}\right)$} & 0.137 & 0.117 & 0.137 \\
\hline & $(1.96)^{* * *}$ & $(2.03)^{* *}$ & $(1.95)^{* * *}$ \\
\hline \multirow[t]{2}{*}{$\ln \left(\mathrm{Tchr}_{\mathrm{ijt}}\right)$} & -0.023 & -0.062 & -0.023 \\
\hline & $(-1.20)$ & $(-3.86)^{* * *}$ & $(-1.20)$ \\
\hline \multirow[t]{2}{*}{ Acc $_{\mathrm{ijt}}$} & 0.161 & 0.167 & 0.161 \\
\hline & $(8.16)^{* * *}$ & $(8.49)^{* * *}$ & $(8.15)^{* * *}$ \\
\hline \multirow[t]{2}{*}{$\mathbf{L} \mathbf{c}_{\mathrm{ij}}$} & - & -0.037 & 1.572 \\
\hline & - & $(0.84)$ & $(0.89)$ \\
\hline \multirow[t]{2}{*}{$\mathbf{C b}_{\mathrm{ij}}$} & - & 0.084 & 2.206 \\
\hline & - & $(0.205$ & $(0.66)$ \\
\hline$D_{t}$ & $* * *$ & $* * *$ & $* * *$ \\
\hline \multirow[t]{2}{*}{ Constant } & -5.679 & -3.218 & -2.177 \\
\hline & $(-4.84) * * *$ & $(-5.61) * * *$ & $(-2.39) * *$ \\
\hline $\mathrm{N}^{0}$. Observations & 1368 & 1368 & 1368 \\
\hline $\mathrm{N}^{\mathrm{o}}$. groups & 76 & 76 & 76 \\
\hline R-squared & 0.71 & 0.78 & - \\
\hline $\mathrm{VIF}^{14}$ & 0.37 & 1.33 & - \\
\hline $\begin{array}{l}\text { Ramsey-Reset } \\
\text { Prob }>\mathrm{Chi}^{2}\end{array}$ & $\begin{array}{l}31.97 \\
(0.0)\end{array}$ & $\begin{array}{c}2561.08 \\
(0.00)\end{array}$ & - \\
\hline $\begin{array}{l}\text { Breusch - Pagan / Cook }- \text { Weisberg }{ }^{16} \\
\text { (before correction) Prob }>\text { chi2 }\end{array}$ & $\begin{array}{l}24.85 \\
(0.00)\end{array}$ & $\begin{array}{c}13616.56 \\
(0.00)\end{array}$ & - \\
\hline $\begin{array}{l}\text { Hausman test } \\
\text { Prob }>\mathrm{Chi}^{2}\end{array}$ & - & $\begin{array}{l}16.68 \\
(0.78)\end{array}$ & - \\
\hline
\end{tabular}

\footnotetext{
${ }^{14}$ VIF test for multicolinearity calculates the variance inflation factors for the independent variables specified in the fitted model.

${ }^{15}$ Ramsey Reset test can be used to test for a multitude of specification problems including omitted variables (see Wooldridge, 2002). It amounts to testing $\mathrm{y}=\mathrm{xb}+\mathrm{zt}+\mathrm{u}$ and then testing $\mathrm{t}=0$. If no option is specified, powers of the fitted values are used for $\mathrm{z}$ and otherwise powers of the individual elements of $\mathrm{x}$ are used.

${ }^{16}$ Breusch Pagan/Cook Weisberg test for heteroskedasticity performs a score test for $\mathrm{H}: \mathrm{b}=0$ against multiplicative heteroskedasticity; $\operatorname{var}(\mathrm{y})=\mathrm{s}^{\wedge} 2 \exp \left(\mathrm{b}_{1} \mathrm{z}_{1}+\mathrm{b}_{2} \mathrm{z}_{2}+\ldots+\mathrm{b}_{\mathrm{k}} \mathrm{z}_{\mathrm{k}}\right)$.
} 
In all estimations we can note that the income per capita variable has the expected positive sign which is in accordance with the H-O theory, i.e. trade between two zones is based on comparative advantage. It's a complementary inter-industry trade where less developed countries are specialized in labor intensive industries and where wage costs are less expensive. But, the coefficient is low (0.137) implying that inter-industry trade is reduced in favor of vertical intra-industry trade, which is associated to multinationals strategies of production development on segments of quality. Moreover, an access to a larger market, implies an increase of the trade flows volume (according to coefficient of the size of importer country coefficient). Variables like country size, difference of incomes per capita, which have the most important coefficients explain better the level of bilateral exchanges. The international organization membership has a low influence on trade flows. On the contrary, the distance variable (proxy costs of transport) represents an obstacle for trade. It should be noted that the distance between countries has an important elasticity (-1.621) and hence has an important explanatory capacity.

A comparison between the three estimation leads to the following conclusion. The results of random estimator are different from those obtained with the within estimator, for some explanatory variables. This means that there exists a correlation between some of the explanatory variables and the bilateral specific effect. Moreover, the Hausman test confirms the presence of a correlation and rejects the null assumption of absence of a correlation between the individual effects and explanatory variables. Random estimate is biased, and in this case the use of Hausman-Taylor instrumental variables methods (1981) to correct the bias is justified. Using HT we obtain similar coefficients to FEM and also we highlight the time - invariant variables and their important influence on trade flows. We note that the coefficient of the distance is higher than the other estimates but is in accordance with other papers ${ }^{17}$.

\footnotetext{
${ }^{17}$ See Peter Egger (2000).
} 


\section{Conclusion}

In this article, we have investigated trade flows between CEEC and OECD countries using recent developments of panel data techniques with fixed effects, which permit to control the individual heterogeneity and hence, to avoid biased results. Indeed, it is now well known that the use of conventional time-series and cross-section methods do not allow to control for unobservable heterogeneity and hence, are likely to produce biased results 18 . Our empirical results enable us to draw the following conclusions:

(i) From an econometric point of view, the use of the HT method to estimate the gravity model appears the most convenient for our data sample. More particularly in the presence of correlation between some explanatory variables and the unobserved characteristics (here the unobserved bilateral effect), this method produces consistent parameter estimates contrary to the GLS method. Besides, in contrast to the standard within estimator the HT method allows to derive parameter estimates for the time-invariant variables (such as the geographic distance, the common border, the common language). Our econometric estimations reveal that the country size and the geographical distance variables have a crucial impact in international trade flows explanation and are the most important sources of this correlation.

(ii) From an economic point of view, trade flows existing between CEEC and OECD countries, that is, two sets of heterogeneous economies with different levels of economic development are inter-industry and vertical intra-industry trade. The vertical intra-industry trade was stimulated by the multinational firms, which developed a labour intensive production segment in CEEC countries due to their comparative advantage and their less expensive labour costs than in developed countries. The positive coefficient of the DGDPT variable, which represents a proxy of comparative advantage intensity, emphasized that the economic distance

18 See Badi H. Baltagi (2001). 
between OECD and CEEC countries constitutes the specialization main determinant of these countries on various branches according to their comparative advantages (inter-industry trade), as well as on some qualitative segments within these branches (vertical intra-industry trade). But these types of trade do not actually lead to convergence, the main goal of Central and Eastern European countries. Indeed, economic convergence is associated to an horizontal intraindustry trade, which assumes the existence of simultaneous exports and imports flows of comparable sizes inside the same branch, that is, similar products of the same quality, of the same technology and an important added value. Consequently, horizontal intra-industry trade is an indicator of the convergence degree between countries. However, this type of trade is less developed between CEEC and OECD countries and the tendency to an economic convergence in the short run is unlikely for CEEC countries, since there exist no competing but only complementary market segments. In fact, trade flows are essentially stimulated by price competitiveness.

\section{6. $\quad$ References}

Aitken, N. (1973) The effect of the EEC and EFTA on European trade: a temporal crosssection analysis, American Economic Review, 63, 881-92.

Baier, L. S. and Bergstrand, J. H. (2005) Do free trade agreements actually increase members' international trade?, FRB of Atlanta Working Paper No. 2005-3.

Baldwin, R. E. (1994) Towards an Integrated Europe, CEPR, London.

Bayoumi, T. and Eichengreen, B. (1997) Is regionalism simply a diversion? Evidence from the evolution of the EC and EFTA, NBER Working Paper, No. 5283.

Baltagi, B. H. (2001) Econometric Analysis of Panel Data, 2nd edn, John Wiley \& Sons Ltd, New York.

Beckerman, W. (1956) Distance and the pattern of intra-European trade, Review of Economics and Statistics, 38, 31-40. 
Bergstrand, J. H. (1989) The Generalized Gravity Equation, Monopolistic Competition, and the Factor-Proportions Theory in International Trade. Review of Economics and Statistics, $71,143-53$.

Carrere, C. (2006) Revisiting the effects of regional trading agreements on trade flows with proper specification of gravity model, European Economic Review, 50, 223-47.

Cheng, I.-H. and Wall, H. (2005) Controlling for heterogeneity in gravity models of trade and integration, Federal Reserve Bank of Saint Louis Review, 87, 49-63.

Egger, P. (2000) A note on the proper econometric specification of the gravity equation, Economics Letters, 66, 25-31.

Egger, P. (2002) An econometric view on the estimation of gravity models and the calculation of trade potentials, The World Economy, 25, 297-312.

Egger, P., and Pfaffermayr, M. (2003) Structural Funds, EU Enlargement, and the Redistribution of FDI in Europe, WIFO Working Papers, No. 195.

Evenett, S. J. and Keller, W. (2002) On theories explaining the success of the gravity equation, Journal of Political Economy, (University of Chicago Press), 110, 281-316.

Frankel, J. (1997) Regional trading blocs in the world economic system, Institute for International Economics, Washington.

Festoc, F. (1997) Le potentiel de croissance du commerce des pays d'Europe Centrale et Orientale avec la France et ses principaux partenaires, Economie et Prévision, 218, 161-81.

Ghosh, S. and Yamarik, S. (2004) Are regional trading arrangements trade creating?: an application of extreme bounds analysis, Journal of International Economics, 63, 369-95.

Glick, R. and Rose, A. K. (2002) Does a currency union affect trade? The time-series evidence, European Economic Review, Elsevier, 46, 1125-51.

Gros, D. and Gonciarz, A. (1996) A note on the trade potential of central and eastern Europe, European Journal of Political Economy, 12, 709-21. 
Hausman, J. A. and Taylor, W. E. (1981) Panel data and unobservable individual effects, Econometrica, 49, 1377-98.

Helpman, E. and Krugman, P. (1985) Market Structure and Foreign Trade. Increasing Returns, Imperfect Competition, and the International Economy, MIT Press, Cambridge MA/London.

Linnemann, H. (1966) An Econometric Study of International Trade Flows, North Holland Publishing Company, Amsterdam.

Matyas, L. (1997) Proper econometric specification of the gravity model, The World Economie, 20, 363-8.

Péridy. N. (2006) La nouvelle politique de voisinage de l'Union européenne, une estimation des potentiels de commerce, Revue e'conomique, 57 | ISSN 0035-2764 | ISSN numérique: en cours | ISBN: 2-7246-3037-8 | pp. 727-46.

Poyhonen, P. (1963) A Tentative Model for the Volume of Trade between Countries, Weltwirtschaftliches Archiv, 90, 93-9.

Rault C., Sova A., Sova R. (2007) The Endogeneity of Association Agreements and their Impact on Trade for Eastern Countries: Empirical Evidence for Romania, William Davidson Institute Working Paper Number, 868.

Rault C., Sova A. Sova R. (2007) The Role of Association Agreements Within European Union Enlargement to Central and Eastern European Countries, IZA Discussion Paper No. 2769.

Rose, A. K. (2000) One money one market, The effect of common currencies on trader, Economic Policy, 15, 7-46.

Sapir, A, and Winter, C. (1994) Services Trade. In Surveys in International Trade, (Eds) D. Greenaway and L. Alan Winters. Oxford, UK: Blackwell.

Soloaga, I. and Winters, A. L. (2001) Regionalism in the nineties: what effect on trade?, The North American Journal of Economics and Finance, Elsevier, 12, 1-29. 
Tinbergen J. (1962) Shaping the world economy: suggestions for an international economic policy, Twentieth Century Fund, New York.

Wei, S. J. and Frankel, J. A. (1998) Open regionalism in a world of continental trade blocs, IMF Staff Papers, International Monetary Fund, 45, 2.

Wooldrige, J. H. (2002) Econometric Analysis of Cross Section and Panel Data, 2nd edn, The MIT Press Cambridge, Massachusetts London, England.

Wooldrige, J. H. (2005) Introductory Econometrics: A modern approach, 3rd edn, Thomson South-Western, ISBN 0-324-28978-2. 


\section{CESifo Working Paper Series}

for full list see www.cesifo-group.org/wp

(address: Poschingerstr. 5, 81679 Munich, Germany, office@cesifo.de)

2217 Hartmut Egger and Peter Egger, The Trade and Welfare Effects of Mergers in Space, February 2008

2218 Dorothee Crayen and Joerg Baten, Global Trends in Numeracy 1820-1949 and its Implications for Long-Run Growth, February 2008

2219 Stephane Dees, M. Hashem Pesaran, L. Vanessa Smith and Ron P. Smith, Identification of New Keynesian Phillips Curves from a Global Perspective, February 2008

2220 Jerome L. Stein, A Tale of Two Debt Crises: A Stochastic Optimal Control Analysis, February 2008

2221 Michael Melvin, Lukas Menkhoff and Maik Schmeling, Automating Exchange Rate Target Zones: Intervention via an Electronic Limit Order Book, February 2008

2222 Raymond Riezman and Ping Wang, Preference Bias and Outsourcing to Market: A Steady-State Analysis, February 2008

2223 Lars-Erik Borge and Jørn Rattsø, Young and Old Competing for Public Welfare Services, February 2008

2224 Jose Apesteguia, Steffen Huck, Jörg Oechssler and Simon Weidenholzer, Imitation and the Evolution of Walrasian Behavior: Theoretically Fragile but Behaviorally Robust, February 2008

2225 Walter Krämer, Long Memory with Markov-Switching GARCH, February 2008

2226 António Afonso and Christophe Rault, What do we really Know about Fiscal Sustainability in the EU? A Panel Data Diagnostic, February 2008

2227 Sergey M. Kadochnikov and Igor M. Drapkin, Market Structure, Technological Gap and Vertical Linkage Effects from Foreign Direct Investment, February 2008

2228 Guglielmo Maria Caporale, Davide Ciferri and Alessandro Girardi, Fiscal Shocks and Real Exchange Rate Dynamics: Some Evidence for Latin America, February 2008

2229 Scott Alan Carson, Geography and Insolation in $19^{\text {th }}$ Century US African-American and White Statures, February 2008

2230 Wolfgang Buchholz and Jan Schumacher, Discounting and Welfare Analysis Over Time: Choosing the $\eta$, February 2008

2231 M. Hashem Pesaran, Christoph Schleicher and Paolo Zaffaroni, Model Averaging in Risk Management with an Application to Futures Markets, February 2008 
2232 Wilhelm Kohler, Offshoring: Why Do Stories Differ?, February 2008

2233 Stefan Bach, Giacomo Corneo and Viktor Steiner, Effective Taxation of Top Incomes in Germany, 1992-2002, February 2008

2234 Robert S. Chirinko, $\sigma:$ The Long And Short Of It, February 2008

2235 Volker Grossmann and Holger Strulik, Should Continued Family Firms Face Lower Taxes than other Estates?, February 2008

2236 Guido Tabellini, The Scope of Cooperation: Values and Incentives, February 2008

2237 Heinrich W. Ursprung and Christian Wiermann, Reputation, Price, and Death: An Empirical Analysis of Art Price Formation, March 2008

2238 Hans Fehr and Christian Habermann, Private Retirement Savings in Germany: The Structure of Tax Incentives and Annuitization, March 2008

2239 Joseph Francois and Ian Wooton, Market Structure and Market Access, March 2008

2240 Hiroyuki Kasahara and Beverly Lapham, Productivity and the Decision to Import and Export: Theory and Evidence, March 2008

2241 Gary E. Bolton and Axel Ockenfels, Does Laboratory Trading Mirror Behavior in Real World Markets? Fair Bargaining and Competitive Bidding on EBay, March 2008

2242 Atsushi Oshima, B. Ravikumar and Raymond Riezman, Entrepreneurship, Organization Capital and the Evolution of the Firm, March 2008

2243 Walter Krämer and Sebastian Schich, Large-Scale Disasters and the Insurance Industry, March 2008

2244 Leif Danziger, Adjustment Costs, Inventories and Output, March 2008

2245 Anne van Aaken, Lars P. Feld and Stefan Voigt, Power over Prosecutors Corrupts Politicians: Cross Country Evidence Using a New Indicator, March 2008

2246 Hans-Christian Heinemeyer, Max-Stephan Schulze and Nikolaus Wolf, Endogenous Borders? The Effects of New Borders on Trade in Central Europe 1885-1933, March 2008

2247 Johannes Becker and Clemens Fuest, Tax Competition - Greenfield Investment versus Mergers and Acquisitions, March 2008

2248 Giorgio Bellettini and Hubert Kempf, Why not in your Backyard? On the Location and Size of a Public Facility, March 2008

2249 Jose Luis Evia, Roberto Laserna and Stergios Skaperdas, Socio-Political Conflict and Economic Performance in Bolivia, March 2008 
2250 Bas Jacobs and A. Lans Bovenberg, Optimal Taxation of Human Capital and the Earnings Function, March 2008

2251 Jan-Egbert Sturm and Timo Wollmershäuser, The Stress of Having a Single Monetary Policy in Europe, March 2008

2252 Guido Schwerdt, Labor Turnover before Plant Closure: 'Leaving the Sinking Ship' vs. 'Captain Throwing Ballast Overboard', March 2008

2253 Keith E. Maskus and Shuichiro Nishioka, Development-Related Biases in Factor Productivities and the HOV Model of Trade, March 2008

2254 Jeremy Edwards and Sheilagh Ogilvie, Contract Enforcement, Institutions and Social Capital: the Maghribi Traders Reappraised, March 2008

2255 Imed Drine and Christophe Rault, Purchasing Power Parity for Developing and Developed Countries. What can we Learn from Non-Stationary Panel Data Models?, March 2008

2256 Scott Alan Carson, Health, Wealth and Inequality: a Contribution to the Debate about the Relationship between Inequality and Health, March 2008

2257 C.A.E. Goodhart, The Regulatory Response to the Financial Crisis, March 2008

2258 Stefan Bauernschuster, Oliver Falck and Stephan Heblich, The Impact of Continuous Training on a Firm's Innovations, March 2008

2259 Michael Grimm and Stephan Klasen, Geography vs. Institutions at the Village Level, March 2008

2260 Fwu-Ranq Chang, Property Insurance, Portfolio Selection and their Interdependence, March 2008

2261 J. Atsu Amegashie and Marco Runkel, The Paradoxes of Revenge in Conflicts, March 2008

2262 Hans Jarle Kind, Marko Koethenbuerger and Guttorm Schjelderup, Efficiency Enhancing Taxation in Two-sided Markets, March 2008

2263 M. Hashem Pesaran, Til Schuermann and L. Vanessa Smith, Forecasting Economic and Financial Variables with Global VARs, March 2008

2264 Volker Grossmann, Entrepreneurial Innovation and Sustained Long-run Growth without Weak or Strong Scale Effects, March 2008

2265 Robert S. Chirinko and Huntley Schaller, The Irreversibility Premium, March 2008

2266 Andrea Galeotti and José Luis Moraga-González, Platform Intermediation in a Market for Differentiated Products, April 2008 
2267 Torben M. Andersen and Michael Svarer, The Role of Workfare in Striking a Balance between Incentives and Insurance in the Labour Market, April 2008

2268 Harald Badinger, Cyclical Fiscal Policy, Output Volatility, and Economic Growth, April 2008

2269 Thomas Aronsson and Erkki Koskela, Outsourcing and Optimal Nonlinear Taxation: A Note, April 2008

2270 Gary E. Bolton, Claudia Loebbecke and Axel Ockenfels, How Social Reputation Networks Interact with Competition in Anonymous Online Trading: An Experimental Study, April 2008

2271 Nikolaus Wolf, Scylla and Charybdis. Explaining Europe's Exit from Gold, January 1928 - December 1936, April 2008

2272 Michael Funke and Marc Gronwald, The Undisclosed Renminbi Basket: Are the Markets Telling us something about where the Renminbi - US Dollar Exchange Rate is Going?, April 2008

2273 Thor Olav Thoresen and Annette Alstadsæter, Shifts in Organizational Form under a Dual Income Tax System, April 2008

2274 Helge Berger and Volker Nitsch, Too many Cooks? Committees in Monetary Policy, April 2008

2275 Yin-Wong Cheung and Eiji Fujii, Deviations from the Law of One Price in Japan, April 2008

2276 Michael S. Michael, Sajal Lahiri and Panos Hatzipanayotou, Integrated Reforms of Indirect Taxes in the Presence of Pollution, April 2008

2277 Bas Jacobs, Is Prescott Right? Welfare State Policies and the Incentives to Work, Learn and Retire, April 2008

2278 Burkhard Heer and Alfred Maußner, Value Function Iteration as a Solution Method for the Ramsey Model, April 2008

2279 Jarko Fidrmuc and Christa Hainz, Integrating with their Feet: Cross-Border Lending at the German-Austrian Border, April 2008

2280 Kristof Dascher and Alexander Haupt, The Political Economy of Regional Integration Projects at Borders where Rich and Poor Meet: The Role of Cross-Border Shopping and Community Sorting, April 2008

2281 Katrin Assenmacher-Wesche and M. Hashem Pesaran, A VECX* Model of the Swiss Economy, April 2008

2282 Christophe Rault, Robert Sova and Ana Maria Sova, Modeling International Trade Flows between CEEC and OECD Countries, April 2008 